\title{
2013 年度「日本のライフラインを支える電力設備」シンポジウム
}

電気学会 電力・エネルギー部門 静止器技術委員会では, 「日本のライフラインを支える電力設備」と題し, 大学生, 大学 院生, 新社会人（特に, 就職活動を控えた大学 3 年生, 大学院 1 年生にも, ぜひご紹介ください! ) を対象とした, 電力に 関する講義を履修したことの無い初学者にも理解できるような, 基礎から分かり易く解説するシンポジウムを下記により開催 いたします。本セミナーを通して，世界一の電力品質を持ち災害にも強い日本の電力エネルギ一技術を，若い世代に広く啓発 活動し, 電力エネルギ一業界に興味を持ってもらうと同時に, 静止器技術の普及促進とさらなる発展に寄与できれば幸いと存 じます。奮ってで参加賜りますようお願い申し上げます。

記

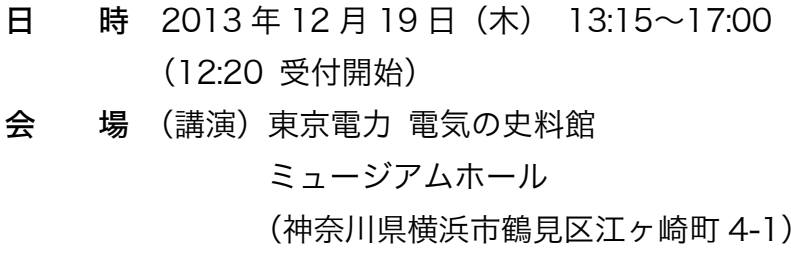

（見学）東京電力 電気の史料館

最寄駅：JR 東日本 尻手駅 徒歩 18 分

プログラム (予定)

「電力系統とこれを支える静止器」

「電力エネルギーの安定供給を支える変圧器技術」

「電力品質を支えるコンデンサ技術」

「遮断器 一電流を切るための技術動向一」

「電力安定供給を支える送電技術」

「電力エネルギー機器の設計のための電磁界数值 シミュレーション」

主 催 電気学会 電力・エネルギー部門 静止器技術委員会
講演会後は, 電気の史料館の見学を行います。

対 象 参加資格不問

(どなたでもご自由に参加下さい。)

特に大学生, 大学院生, 新社会人の参加を歓迎 します。

参 加 費 無料

申込期限 2013 年 12 月 13 日（金）

（申し込み人数が 50 名になり次第締め切ります。）

申 込 先 電子メールにて, 下記宛てに申し込み下さい。 東京都市大学 工学部 電気電子工学科

岩尾徹

E-mail : toruiwao@mem.iee.or.jp

申込みの際には, 申込カテゴリ (一般・大学教職員 · 大学 生・大学院生), 氏名, 所属, 電子メールアドレスを併せて お知らせ下さい。

\section{特集号の論文募集}

\begin{tabular}{|c|c|c|c|}
\hline 特集テーマ & 掲載予定号 & 投稿締切 & 詳細掲載 \\
\hline 『最近の電線・ケーブル技術』特集 & 平成 26 年 8 月号 & 平成 25 年 9 月 30 日 & N L 8 月号 \\
\hline
\end{tabular}

